\title{
AN INVESTIGATION INTO DIFFICULTIES IN ENGLISH LISTENING OF FRESHMEN MAJORING IN ENGLISH AT A UNIVERSITY IN THE MEKONG DELTA, VIETNAM
}

\author{
Thi Bao Dung Dang, \\ Van Lanh Le ${ }^{\mathrm{i}}$, \\ My Nguyen, \\ Van Si Vo, \\ Nhu Ngoc Hua
} Faculty of Linguistics and Literature, Tay Do University, Can Tho City, Vietnam

\begin{abstract}
:
English is a very popular language in the world. However, learning a foreign language is not an easy process for learners, especially the English listening process. In fact, most learners believe that it is hard for them to master this skill. Therefore, the research "An Investigation into Difficulties in English Listening of Freshmen Majoring in English at a University in the Mekong Delta" was conducted with the purpose of helping these students to recognize clearly their own problems in English listening. Statistical data were collected from eighty-five English-majored freshmen. The main instrument of the study was a questionnaire. The findings of the research would point out the students' difficulties in linguistics, including vocabulary, grammar, pronunciation, intonation and accent; background knowledge; and difficulties from their own minds. One more notable purpose of this research is that thanks to the results, students can now solve their own problems, so that they can study better.
\end{abstract}

Keywords: difficulties, English listening, freshmen

\section{Introduction}

Today, we are living in a world in which the interweaving and merging of cultures and economies between countries has become a popular trend, and thus relationships among countries get closer and closer. This tendency demands of people an intelligence in using foreign languages, which is a key factor for communication with other people. English, the language for international communication, is "one of the world's most important

i Correspondence: email lvlanh@tdu.edu.vn 
languages" (Graddol, 2004). In addition, since Vietnam's open - door policy, its integration into the global economy, and its attractive destination for tourism and business opportunities, Vietnamese people's need for using English to communicate has increased significantly. Therefore, there is no doubt that English plays a very important role in our lives, and this fact strongly affects language learning in a great number of countries. However, according to Epictetus, nature has given men one tongue but two ears, that we may hear from others twice as much as we speak; therefore, undoubtedly, listening is a prominent skill, which is hard to master and plays a significant role in communication. In fact, if there is no listening, people realize that it is not easy to share their thoughts, feelings, or ideas with others. In life, we are not only listening to the denotative meaning, but also to the figurative sense of the speaker. Furthermore, there will be an invisible distance between person and person, so people communicate with each other by using much more listening skill to get closer. Listening is a complex and very long-term process; hence students should spend much more time practicing by themselves.

In reality, one more notable thing is that almost all students at Tay Do University, especially the English-majored freshmen, usually feel worried, and lack confidence when they are listening to English; thus, they get low marks in listening tests. There are many reasons for this problem. The first one is that many of them who come from the countryside lack chances to practice and get little training in listening skills at high school. They are taught by traditional methods, using the traditional grammar - translation method of teaching English, instead of the communicative approach, which causes students to form their own ineffective listening habits. For instance, they try to understand word by word or sentence by sentence, even trying to translate English to Vietnamese in their minds while listening. In addition, they commonly wait for information from lecturers instead of actively finding their own materials for learning. Also, they do not apply effective listening strategies that they have learnt from their teachers. Moreover, they do not have enough vocabulary, pronunciation, intonation, and accent, nor grammar and background knowledge to understand the listening test. All these bring students problems in the listening process.

Correspondingly, this research was conducted to discover the problems facing English-majored freshmen at Tay Do University when learning listening. Hopefully, this research can assist students on the way to recognizing their difficulties. Furthermore, it will be easier for students to overcome their own difficulties in listening and improve their listening skills if they rely on the problems stated in this research.

\subsection{Research aims and research question}

\subsubsection{Aim of the study}

This study aimed to investigate the common problems that freshmen majoring in English at Tay Do University had to face when learning English listening. Furthermore, it was hoped that students could easily reduce their difficulties and improve their listening skills effectively. 


\subsubsection{Research question}

The research was conducted to deal with this research question: What are the difficulties in English listening of freshmen majoring in English at Tay Do University?

\subsection{The significance of the research}

This study was expected to help students more easily realize their own problems in English listening and become aware of the effects of these factors, particularly freshmen majoring in English at Tay Do University. It was also hoped that they could improve their listening skills thanks to the problems mentioned in this research.

\subsection{The organization}

The research is divided into five chapters:

Chapter 1: Introduction

Chapter 2: Literature review

Chapter 3: Research methodology

Chapter 4: Findings and Discussion

Chapter 5: Conclusion, Implications, Limitations and Recommendations

\section{Literature review}

\subsection{Definitions of listening}

"To be attentive means to listen without any interpretation, without any judgment - just to listen. When you are so listening, there is no boundary." (Krishnamurti, 1973)

In communication, not everyone can closely connect with other people because it is not an easy process. Many people think that communication is talking - and talk we do. We interrupt, advise, reassure, judge, analyze, criticize, argue, moralize, threaten, divert, diagnose, etc. But good communication requires good listening as well as talking. In fact, since we have two ears and only one mouth, listening just might be the more important skill (Simon \& Schuster, 1979). In addition, listening is one important ingredient to success in personal and professional life. Those who master the art of listening will at the very least be regarded positively (Purdy \& Borisoff, 1997).

There are many other definitions about listening. Howett and Dakin (1974) define that "listening is the ability to identify and understand what others are saying. This involves understanding a speaker's accent or pronunciation, his grammar and his vocabulary, and grasping his meaning". Also, listening is receiving language through the ears. Listening involves identifying the sounds of speech and processing them into words and sentences. When we listen, we use our ears to receive individual sounds (letters, stress, rhythm and pauses) and we use our brain to convert these into messages that mean something to us. In addition, Rost (2002) defines listening, in its broadest sense, as a process of receiving what the speaker actually says; constructing and representing; negotiating meaning with the 
speaker and responding; and creating meaning through involvement, imagination and empathy.

To sum up, listening is the active dynamic process of attending, perceiving, interpreting, remembering and responding to the expressed (verbal and nonverbal) needs, concerns and information offered by other human beings (Purdy, 1997). This is a definition that encompasses the official definitions and is at the same time more specific, emphasizing the need for attention, perceiving and interpreting, and remembering. In addition, it focuses our attention on the all - important needs and concerns of real people (Purdy \& Borisoff, 1997).

\subsection{The role of listening}

Listening plays a vital role in learning not just languages, but any branch of knowledge. When students attend classes, they are expected to comprehend and retain information from lectures. In language classrooms, most of these lectures would range from grammar, pronunciation, word stress, vocabulary, syntax, etc. It should be emphasized that comprehension of messages conveyed can be based on tone of voice, pitch and accent; and it is only possible when we listen (Swoosh, 2013). Further, listening is not only utilized as a language skill for academics but is also considered an absolutely essential skill in life. In fact, listening is a major part in the communication process. Mastering this skill is crucial to understanding messages that people encounter everyday. For instance, people spend about $45 \%$ of their communicating time on listening, 30\% speaking, $16 \%$ reading, and 9\% writing (Feyten, 1991). In addition, Oxford (1993) affirms that listening is the most fundamental skill to the other three (speaking, reading, and writing). Similarly, through listening, people gain a large portion of their education - their information, their understanding of the world and of human affairs, their ideals, sense of values, and their appreciation (Bulletin, 1952). Thus, there is no doubt that an individual, on average, spends the most time on listening. Furthermore, in communication, the role of listening is just as essential. Without being able to listen and understand what has been said, it is impossible to take a meaningful part in most conversations. As Underwood (1989) agrees, if students do not learn to listen effectively, they will be unable to take part in oral communication. In conclusion, without listening skills, language learning is impossible. That is the reason why students majoring in English should pay attention to this skill.

\subsection{Factors affecting listening skills}

In Vietnam, the number of people learning English is not a small figure. But, in fact, not everyone learning English can also be confident in communication. When we were children, the way that we learnt a language was only through listening and learning from our parents. Similarly, it is very hard for learners who do not listen to English regularly to achieve satisfactory results, and that is no exception to English-majored freshmen at Tay Do University. In this study, there are two common factors affecting students' listening skill. 


\subsubsection{Linguistic factors}

One of the most important factors leading students to succeed in listening is linguistic knowledge. It includes many elements such as vocabulary, pronunciation, grammar, etc.

\subsubsection{Vocabulary}

Vocabulary has considerable impact on learners' listening skill. It can help learners who know many words to understand the message better and vice versa. According to Wilkins, D. (1972), "without grammar very little can be conveyed, without vocabulary nothing can be conveyed". It shows that vocabulary is one of the most important parts in the process of learning language in general, and for English in particular. In addition, Richard and Gennady (2002, p.252) also point out that "vocabulary is a core component of language proficiency and provides much of the basics for how well language learners speak, listen, read and write".

This confirm to Boyle's (1984) study, which provided empirical support to the claim that unskilled learners were easily distracted by unknown words. They tend to become nervous and try to think about unfamiliar words while listening, instead of ignoring them and paying attention to the subsequent sentences. As a result, the listeners fail in listening comprehension. This implies that, for many learners, knowing the meaning of words in the text is crucial for their ability to comprehend. In the same way, a majority of learners believed that "meaning resides exclusively within those unfamiliar words" (Hasan, 2000, p.143). In other words, when facing new words, listeners attempted to find out their meaning, rather than inferring the meaning from the context or relevant prior knowledge. Consequently, when they find themselves unable to understand unfamiliar words, they found it difficult to comprehend the meaning of the text. This leads them to miss keywords and other important information from the text. Therefore, it has been said that a large vocabulary size can help listeners achieve better comprehension (Yang, 2002). In addition, it has been found that greater involvement with unfamiliar words led to better retention (Hulstifil \& Laufer, 2001).

From the above points, it seems reasonable to infer that vocabulary plays a significant role in learners' listening skills. The richer learners' vocabulary is, the better their listening comprehension is. Hence, to improve listening skills, learners should enrich their vocabulary as much as possible.

\subsubsection{Grammar}

When learning a language, grammar is unmissable if the learners want to study well. However, in fact, using two languages well at the same time is not easy at all because the grammatical structures of Vietnamese and English are completely different.

In linguistics, grammar is the set of structural rules governing the composition of clauses, phrases, and words in any given natural language. The term, which refers also to the study of such rules (and this field includes morphology, syntax, and phonology), is often complemented by phonetics, semantics and pragmatics (from Wikipedia). In particular, grammar is the rules of words and how words combine together in a language. 
Thus, it is undeniable that grammar plays an important role in listening, speaking, reading and writing skills.

An English student who, although knowing a lot of vocabulary, does not know the way to combine it accurately, cannot master listening skills, nor the English language. In contrast, if learners have good knowledge of grammar, they will study English well by using different and appropriate structures in forming sentences. It also helps them to recognize sentence structures and understand easily what speakers are saying during the process of listening (Duy, 2015).

\subsubsection{Pronunciation, intonation and accent}

Accuracy of pronunciation plays an important role in listening skills because "if the listener learns to pronounce the sounds accurately himself, it will be much easier for him/her to hear them correctly" (Ur, 1984, p.11). In other words, when using correct sound, the listeners may listen to the listening text correctly. In contrast, if listeners often pronounce some certain words inaccurately, they cannot recognize those words in listening text: "Knowing a lot of vocabulary is meaningless if you cannot pronounce those words correctly and no one can understand the words that you are trying to use" (Anh, 2014). They cannot identify the main information, the meaning of what they hear and grasp the main content: "learners with good English pronunciation are likely to be understood even if they make errors in other areas, whereas learners with bad pronunciation will not be understood, even if their grammar is perfect" (Gilakjani, 2012). Furthermore, students cannot recognize some familiar words when listening if they mispronounce. This becomes a big obstacle in learning English listening.

The information conveyed by a sentence is expressed not only by proper words and grammar structure, but also by intonation and accent. Intonation refers to the rise and fall of the pitch of the voice in spoken language. When people say something, they cannot say it without some kind of intonation; intonation is inevitable in speech (Tench, 1995). Further, intonation is closely interrelated with other factors - not only grammar and vocabulary, but also non-linguistic factors like the roles of the speakers and hearers (who is talking to whom, in what capacity and in what type of situation).This means that a given sentence can have different intonation patterns in different situations (Livbjerg, I. \& Mees, I. M. 2002). Furthermore, intonation is very important because it conveys both meaning and attitude, so when a non-native speaker gets the intonation wrong, he can be misunderstood or sometimes misinterpreted as sounding rude or demanding when this is not intended (From Linguarama International). It is worth noting that accent is another vital element in linguistic knowledge which has strong influence on studying English listening. There is no doubt that it is not easy to distinguish which word the speakers are mentioning when hearing a new accent for the first time because English language has many dialects in different countries such as American English, British English, Australian English, etc. In addition, according to Yagang (1994), the listeners have tendency to get familiar with the accents with which they mostly listen. If listeners are exposed to standard British or American accents, they will face problems in 
understanding other accents. This causes students to become confused in learning English listening, as well as in communication.

\subsubsection{Background knowledge}

Background knowledge (or prior knowledge) makes it easier to learn new things. When we learn, we connect new learning to what we already have in our brains, forming something like a bridge between the old and the new. In other words, background knowledge is all knowledge learners have when entered a learning environment that is potentially relevant for acquiring new knowledge (Campbell, 1948). For a definition, it can be referred that background knowledge includes learners' linguistic knowledge, world knowledge, and understanding about the context. Background knowledge may be acquired when they are entering the situation, and through their past experience. It is very important for English learners. Thus, if students have immense knowledge on many fields, it is easier for them to apply their knowledge to listening texts. On the other hand, if they lack knowledge for understanding what they heard, they will be confused by new words and phrases. In short, background knowledge strongly affects the way in which listeners interpret and understand a message when listening. In addition, successful comprehension in listening takes place when the listener has schematic knowledge, knowledge of the context and systemic knowledge (Anderson \& Lynch, 2000).

\subsubsection{Factors from learners}

Apart from the factors related to linguistic knowledge and background knowledge, there are some other problems that face learners. They are psychological obstacles, learning strategy, practicing time, attitude and motivation.

\subsubsection{Listening strategy}

Some recent studies find that listeners have trouble in listening because they try to understand every word in the text. Encountering some unfamiliar words, they feel confused and miss the next information. Also, they find it difficult to keep up with all the information, and to think ahead or predict what speakers are going to say. Therefore, it is undeniable that listening strategy plays an important role in English listening comprehension. Weinstein and Mayer (1986) propose that listening strategies are behaviors and thoughts that a listener engages in during listening that are intended to influence the listener who is encoding processing. In other words, listening strategies are techniques or activities that contribute directly to the comprehension and recall of listening input. In addition, listening strategies can be classified by how the listener processes the input. In this sense, listening strategies refer to specific actions taken by the listeners to make listening easier, faster, more effective, and more transferable. There are two distinct processes involved in listening comprehension, described as follows:

Top-down strategies are based on the listener; the listener taps into background knowledge of the topic, the situation or context, the type of text, and the language. This background knowledge activates a set of expectations that help the listener to interpret 
what is heard and anticipate what will come next. Top-down strategies include listening for the main idea; predicting; drawing inferences; and summarizing.

Bottom-up strategies are based on the text; the listener relies on the language in the message, that is, the combination of sounds, words, and grammar that creates meaning. Bottom-up strategies include: listening for specific details; recognizing cognates; and recognizing word-order patterns (Richard, 2008). As a result, listening strategies are an essential factor to help learners become more successful in English listening.

\subsubsection{Practicing time}

Practice is the act of rehearsing a behavior over and over, or engaging in an activity again and again, for the purpose of improving or mastering it, as in the phrase "practice makes perfect". Sports teams practice to prepare for actual games. Playing a musical instrument well takes a lot of practice. It is a method of learning and of acquiring experience (from Wikipedia). As in English listening, students cannot succeed without practice because it is one of the key factors to improving their skill in listening texts, as well as in communication. In Tseng's study (2012), he says that it is hard for learners to produce authentic language because they do not have a real language environment, as a Saudi female learner said that she and her friends were able to practice English only in the class. Thus, it is obvious that spending much more time practicing English listening is essential for learners. Furthermore, listening practice in English is also very important because foreign learners of English living and learning English in non-English-speaking countries have limited opportunities for regular long-term oral communication in English with native speakers of English on a variety of topics and issues using comprehensive content and extensive vocabulary (Shelby, 2013). In brief, when a learner listens to English, he does not have to construct in the mind and to say his own sentences in English like in speaking, but has to understand the content of the sentences spoken by English speakers. It is easier for learners to practice and develop better skills in listening comprehension.

\subsubsection{Motivation and attitudes}

There are many factors that might cause the students' low proficiency in English and one of them belongs to motivation. This is because learners' motivation has been widely accepted as a key factor which influences the rate and success of second/foreign language learning (MacDonough, 1983; Ellis, 1994). In addition, MacDonough (1983, p.142) states that "motivation of the students is one of the most important factors influencing their success or failure in learning the language". Motivation is such a complex phenomenon that it cannot be defined by a single widely accepted theory. This is because the term motivation has been viewed differently by different schools of thought. From the behavioristic perspective, motivation is "quite simply, the anticipation of reward" (Brown, 2000, p. 160). Presumably, it can mean different things and it may be affected by: (a) cause, related to personal goals of the learner or outside incentives such as rewards or punishment; (b) behavior, which relates to persistence, effort of the learner or enjoyment; (c) outcomes, 
referring to evaluation of performance and reaction to success or failure (Al-Tamimi \& Shuib, 2009). Furthermore, another study also states that "learners are motivated if they need to learn the language in order to achieve a goal or if they want to communicate with speakers of the target language and learn about the country where the language is spoken" (Nakanishi T, 2002). It makes sense that individuals who are seriously motivated will certainly learn a foreign language, particularly English listening, faster and more efficiently; if one is motivated, he/she has reasons (motives) for engaging in the relevant activities, expends effort, persists in the activities, attends to the tasks, shows desire to achieve the goal, enjoys the activities, and so on (Gardner, 2006, p. 243).

Another factor is learners' attitudes. Like motivation, attitudes include "the projecting of learners' perspective towards something" (Gardner, 2006). In addition, Gardner and Lambert (1972, p.3) state that his (the learner) motivation to learn is thought to be determined by his attitudes towards the other group in particular and by his orientation towards the learning task itself. According to the Oxford Dictionary, attitude means the way of thinking and feeling about something or somebody. More specifically, R. Aiken states that attitudes are "tendencies to evaluate an entity with some degree of favor or disfavor, ordinarily expressed in cognitive, affective and behavioral responses." Entity refers to the object of an attitude and includes various things like individuals, inanimate objects, concepts, social groups, behaviors, etc. One more notable thing is that attitudes are related strongly to motivation; it is evident that people with a negative attitude towards a language could not be motivated learners, and there is evidence to support the correlation between a positive attitude about a language and high achievement (Wilhelm, 1999). Learning a language is closely related to the attitudes towards the languages (Starks \& Paltridge, 1996). Karahan (2007, p.84) avers that "positive language attitudes let learners have positive orientation towards learning English". As such, attitudes may play a very crucial role in language learning as well as in English listening, as they would appear to influence students' success or failure in their learning.

\section{Research methodology}

\subsection{Design}

The survey research was conducted to answer the research question stated in chapter one. The main object in this research were English majored freshmen at Tay Do University in Can Tho City. They would be delivered a questionnaire so that the information about their problems in studying English listening could be collected. This research is a quantitative one.

\subsection{Participants}

The participants of this research included 85 freshmen from English-majored classes course $X$ at Tay Do University. Among them, there were 40 students in English 10A class and 45 students in English 10B class. Actually, there were 55 students in English 10A and 45 students in English 10A; however, only 85 students' responses were valid. They were 
24 males and 61 females. Their ages were from 18 to 22. English is considered as their foreign language and they have been learning English from 7 to 12 years. The main material of English listening at university was the book "Interactions 1 Listening and Speaking, Silver edition" (by Judith Tanka \& Paul Most; McGraw-Hill ESL/ELT, a business unit of the McGraw-Hill Companies). As well as this, the participants practiced some extensive topics given by their teachers in class.

\subsection{Instrument}

A questionnaire was the instrument of this research, without which the research could not have been completed. Information was collected from the students. The role of the questionnaire was to investigate the difficulties of students in English listening.

\begin{tabular}{|l|l|}
\hline Group & Summary of the content of question group \\
\hline a. $1,2,3,4$ & Students' learning background. \\
\hline b. $5,6,7,8$ & Students' motivation and attitude toward their English listening. \\
\hline c. $9,10,11$ & General appreciation about listening. \\
\hline d. From 12 to 21 & Factors from linguistic affecting listening skills. \\
\hline e. From 22 to 30 & Factors from learners affecting listening skills. \\
\hline f. 31,32 & Students' problems about background knowledge. \\
\hline
\end{tabular}

\subsection{Procedure}

In this part, the process of implementing the research is presented. It was done within 14 weeks and the process was divided into 3 steps. All the activities of carrying out the research are listed in the following table:

\begin{tabular}{|l|l|}
\hline Duration & Activities \\
\hline & $\begin{array}{l}\text { 1. Meeting the instructor } \\
\text { Step 1: }\end{array}$ \\
The first six weeks & $\begin{array}{l}\text { 3. Writing the outline. } \\
\text { 4. Designing the questionnaire. }\end{array}$ \\
\hline $\begin{array}{l}\text { Step 2: } \\
\text { From the } 7^{\text {th }} \text { week to the } 8^{\text {th }} \text { week }\end{array}$ & $\begin{array}{l}\text { 1. Delivering questionnaire to the students } \\
\text { to find out their problems. }\end{array}$ \\
\hline $\begin{array}{l}\text { Step 3: } \\
\text { From the } 9^{\text {th }} \text { week to the } 14^{\text {th }} \text { week }\end{array}$ & $\begin{array}{l}\text { 1. Analyzing the collected data } \\
\text { 2. Completing the research. }\end{array}$ \\
\hline
\end{tabular}

\section{Results and Discussion}

\subsection{Results}

This part shows the results of the questionnaire after collecting all the necessary information from 85 English-majored freshmen at Tay Do University. The findings of the questionnaire were classified into three basic items, including students' background, students' motivation and attitude towards English listening, and students' difficulties in learning listening. 


\subsubsection{The students' background}

\subsubsection{Students' learning background}

The time that students spent on learning English listening will be very useful in determining the students' level. The participants' English learning years calculated from this year (2016) will be showed in the following pie chart.

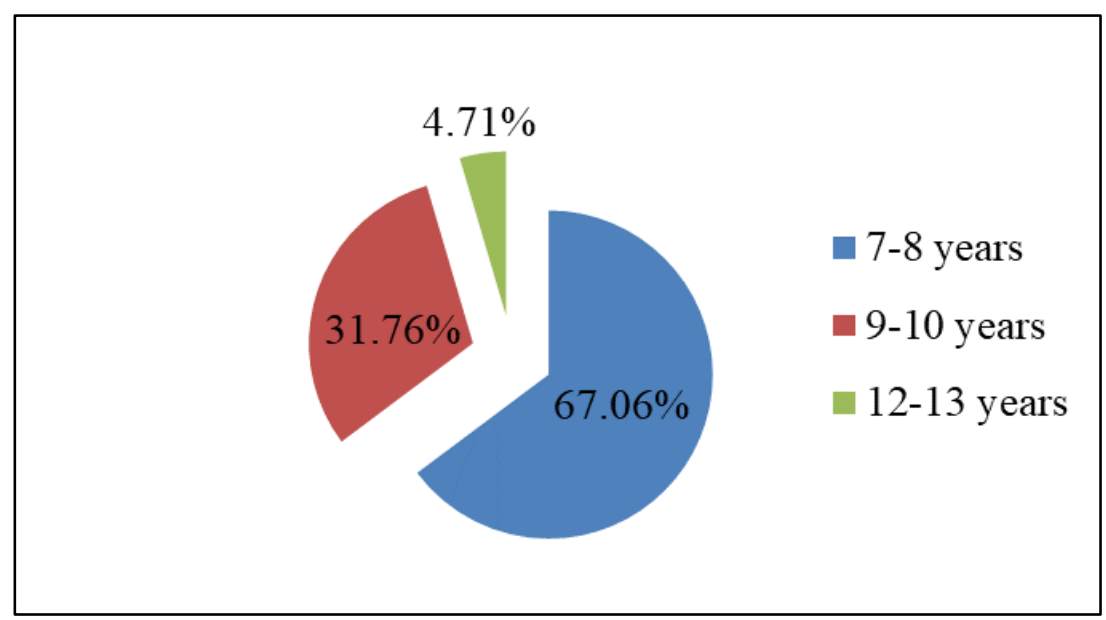

Figure 1: Percentage of students' English learning years

This pie chart indicates that the biggest piece is the one accounting for $67.06 \%$ (54/85) of participants from the English-majored class course 10 at Tay Do University who have been learning English for 7 - 8 years. The remaining ones are 31.76\% (27/85) for 9 10 years, and $4.71 \%$ (6/85) for 12 - 13 years. These figures prove that students have learned English for a long time in primary, secondary or high school before coming to university. However, it does not mean that they had adequate conditions to be good learners because living environment powerfully affects students' English learning. In fact, students' ability to learn a foreign language well or not depends particularly on the place they are from. Thus, knowing the students' learning environment is necessary. To make it clear, look at the following figure.

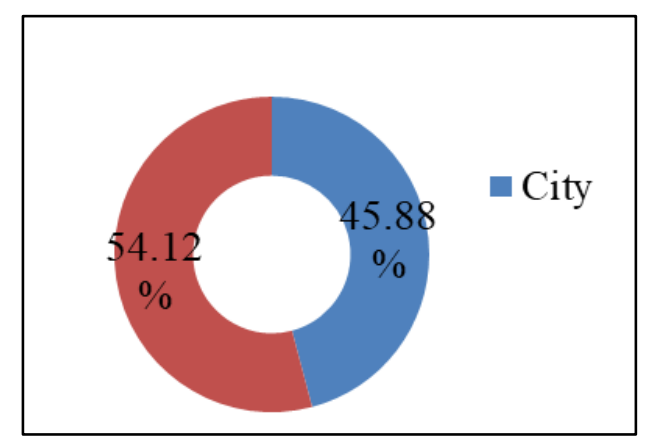

Figure 2: Students' learning environment

Referring to Figure 2, it can be seen that the second group is higher. This shows that $54.12 \%(46 / 85)$ of English-majored freshmen come from the countryside, while $45.88 \%(39 / 85)$ of the students are from the city. Students coming from urban areas have 
many more chances to experience learning via modern equipment as well as new teaching methods, while teachers in rural areas chiefly concentrate on English grammar, reading and writing. That is one of the reasons students experience problems when entering university. Figure 3 is evidence of this.

\subsubsection{Students' motivation and attitude toward English listening}

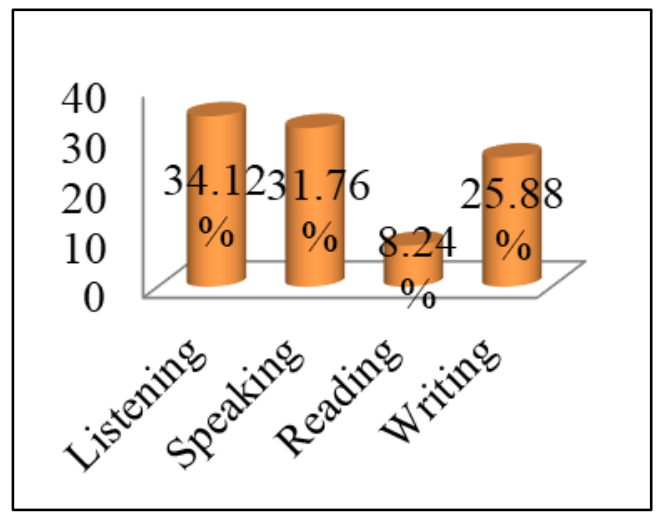

Figure 5: Students' opinions about the most difficult subject

Studying two languages (English and Vietnamese) at the same time is not easy at all for students, especially English-majored freshmen. In addition, they have to learn many skills; there are four main ones, such as speaking, reading, writing and listening. Taking a quick look at the figure, there were only 7 students choosing reading $(8.24 \%)$; and 22 students $(25.88 \%)$ selected writing as the most difficult. $31.76 \%$ of them said that speaking was the most difficult, whereas the other 29 students decided on listening $(34.12 \%)$.

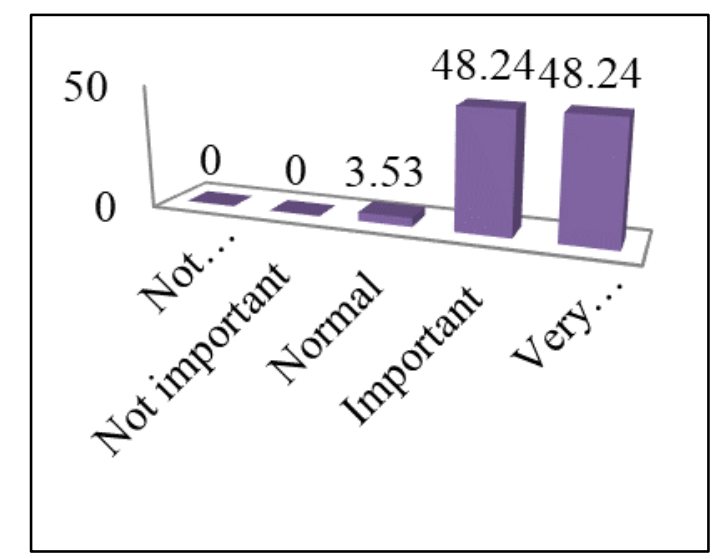

Figure 6: Students' opinions about listening

From the findings in the figure, it is not difficult to see that the percentage of freshmen who confirmed that listening was important was very high (nearly $100 \%$ ). Actually, the percentage of students who believed that listening was a very important subject were $48.24 \%$, and $48.24 \%$ of them also stated listening was important. In contrast, 
there were only $3.53 \%$ of them who thought that it was normal; and no one agreed that listening was not important or not important at all. Thus, from their viewpoints may result these responses for the three statements.

Table 1: The findings of statements about

participants' opinions towards the importance of listening

\begin{tabular}{|l|c|c|c|c|c|}
\hline Statement & $\begin{array}{c}\text { Strongly } \\
\text { agree }\end{array}$ & Agree & No idea & Disagree & $\begin{array}{c}\text { Strongly } \\
\text { disagree }\end{array}$ \\
\hline $\begin{array}{l}\text { 9. Listening is a prominent skill that } \\
\text { is hard to master. }\end{array}$ & $8.24 \%$ & $50.59 \%$ & $27.06 \%$ & $14.12 \%$ & $0 \%$ \\
\hline $\begin{array}{l}\text { 10. Listening is one important } \\
\text { ingredient to succeed in learning a } \\
\text { foreign language. }\end{array}$ & $35.29 \%$ & $60.00 \%$ & $1.18 \%$ & $3.53 \%$ & $0 \%$ \\
\hline $\begin{array}{l}\text { 11. Listening is key to all effective } \\
\text { communication }\end{array}$ & $31.76 \%$ & $58.82 \%$ & $7.06 \%$ & $2.35 \%$ & $0 \%$ \\
\hline
\end{tabular}

From the table, it is clear that the percentage of the respondents who strongly disagreed with the three statements was zero while the percentage choosing "strongly agree" and "agree" was almost overwhelming. In fact, most of them found that "listening is a prominent skill which is hard to be master" $(8.24 \%$ of students in strong agreement and $50.59 \%$ in agreement), whereas $14.12 \%$ of them disagreed and $27.06 \%$ of them gave "no idea" as an answer. Similarly, many of them were also aware of the listening role in learning a foreign language and in communication. In particular, 60\% of students believed that "listening is one important ingredient to succeed in learning a foreign language" and $35.29 \%$ of them strongly agreed with this, while only $3.53 \%$ of them disagreed and $1.18 \%$ were neutral. In addition, the number of respondents who agreed with the statement "listening is key to all effective communication" was also high (31.76\% of students decided on "strongly agree" and 58.82\% of them on "agree"); on the contrary, only $2.35 \%$ of them disagreed and $7.06 \%$ of them had no idea about this statement.

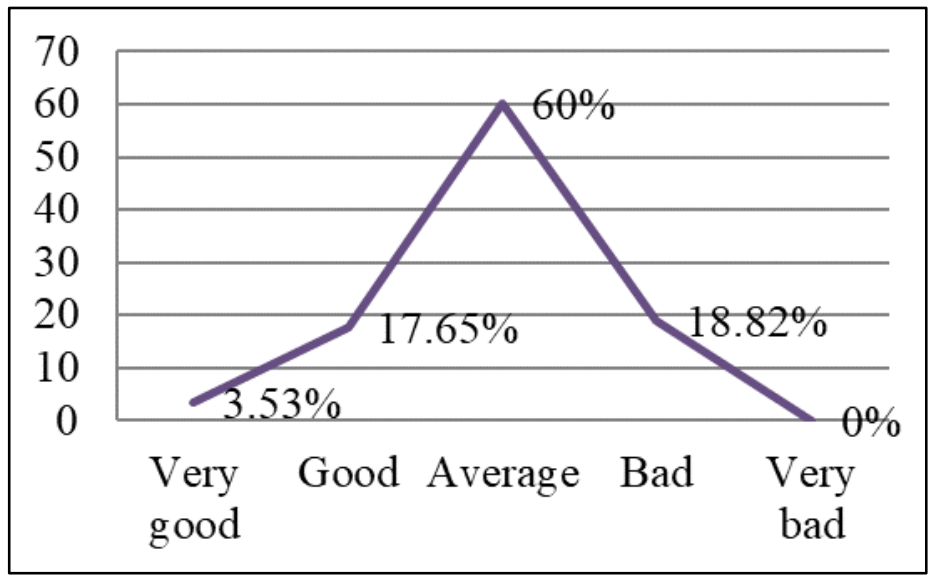

Figure 7: The freshmen's listening level 
Another point is that although nearly $100 \%$ of students realized the importance of English listening, their level of listening skill was not good. With the question "What do you think about your listening skill?" most of them said that their listening skill was medium level (51/85 students) and $18.82 \%$ (16/85) of students said their level was bad. On the other hand, the percentages of students whose skill was good and very good were low. They were less than 25\% - comprising 17.65\% (15/85) of "good" and 3.53\% (3/85) of "very good". Practicing time on learning English listening is one of the factors affecting their skill, as shown below.

Table 2: Students' daily practicing time

\begin{tabular}{|l|c|}
\hline Time & Percentage \\
\hline More than 2 hours & $5.58 \%$ \\
\hline $1-2$ hours & $47.06 \%$ \\
\hline Less than 1 hour & $41.18 \%$ \\
\hline 0 minute & $5.58 \%$ \\
\hline
\end{tabular}

According to the table, there were only 5.58\% (5/85) of students who spent more than 2 hours on practicing listening. The percentage of those who spent from 1 to 2 hours a day listening to English was $47.06 \%$ (40/85). Yet the table also shows that $41.18 \%(35 / 85)$ of the participants only spent less than one hour a day on practicing English listening and 5.58\% (5/85) of them did not spend time doing that. From the statistical data, despite awareness of the importance of listening, it is not an easy process for students to master this skill. They still face many problems in studying English listening.

\subsubsection{Students' problems on learning English listening}

\subsubsection{Linguistic problems}

\subsection{Vocabulary}

In learning a foreign language, we cannot deny the fact that vocabulary plays a vital role in studying listening. Thanks to this, learners can easily acquire listening skills. In contrast, it is also one of the biggest problems that students have to face in the process of learning English listening. The statistic about their vocabulary is shown in the table below:

Table 3: The result of statements about students' vocabulary

\begin{tabular}{|l|c|c|c|c|c|}
\hline Statements & $\begin{array}{c}\text { Strongly } \\
\text { agree }\end{array}$ & Agree & No idea & Disagree & $\begin{array}{c}\text { Strongly } \\
\text { disagree }\end{array}$ \\
\hline $\begin{array}{l}\text { 12. While listening, you usually become } \\
\text { nervous whenever facing new words. }\end{array}$ & $12.94 \%$ & $40.00 \%$ & $29.41 \%$ & $17.65 \%$ & $0 \%$ \\
\hline $\begin{array}{l}\text { 13. When you are unable to understand } \\
\text { unfamiliar words, it is difficult to } \\
\text { comprehend the meaning of the text. }\end{array}$ & $12.94 \%$ & $57.65 \%$ & $16.47 \%$ & $11.76 \%$ & $1.18 \%$ \\
\hline $\begin{array}{l}\text { 14. If you lack background knowledge, } \\
\text { you will be confused by new words and } \\
\text { phrases. }\end{array}$ & $20.00 \%$ & $74.12 \%$ & $4.71 \%$ & $1.18 \%$ & $0 \%$ \\
\hline
\end{tabular}


The data in the chart reveal that many students had problems with vocabulary because there was no one picking "Strongly disagree" in statements 12 and 14; and only $1.18 \%$ of them in statement 13 . Concretely, over $50 \%$ of the respondents $(12.94 \%$ of them strongly agreed and $40.00 \%$ agreed) believed that while listening, they usually became nervous whenever facing new words, $17.65 \%$ gave "disagree", and $29.41 \%$ had no idea. The number of students (57.65\% chose "agree" and $12.94 \%$ chose "strongly agree") who agreed with the sentence "when you are unable to understand unfamiliar words, it is difficult to comprehend the meaning of the text" was also higher than the other ones (1.18\% strongly disagreed, $11.76 \%$ disagreed, and $16.47 \%$ had no idea). Similarly, in statement 14 of the questionnaire, about $94.12 \%(74.12 \%$ agreed and $20 \%$ strongly agreed) shared that if they lacked background knowledge, they would be confused about new words and phrases, while a few students (1.18\% of them) did not have problems with it and $4.71 \%$ of them gave no comment.

\subsection{Grammar}

Table 4: Respondents' grammar obstacles in listening

\begin{tabular}{|l|c|c|c|c|c|}
\hline Statements & $\begin{array}{c}\text { Strongly } \\
\text { agree }\end{array}$ & Agree & No idea & Disagree & $\begin{array}{c}\text { Strongly } \\
\text { disagree }\end{array}$ \\
\hline $\begin{array}{l}\text { 15. Incorrect grammar is one of the } \\
\text { obstacles affecting your listening skill. }\end{array}$ & $16.47 \%$ & $58.82 \%$ & $14.52 \%$ & $10.59 \%$ & $0 \%$ \\
\hline $\begin{array}{l}\text { 16. It is hard to understand the exact } \\
\text { meaning of a sentence without } \\
\text { grammatical knowledge. }\end{array}$ & $8.24 \%$ & $62.35 \%$ & $16.47 \%$ & $12.94 \%$ & $0 \%$ \\
\hline $\begin{array}{l}\text { 17. The differences of sentence structures } \\
\text { will result in a variety of meanings and } \\
\text { implications. }\end{array}$ & $9.41 \%$ & $74.12 \%$ & $12.94 \%$ & $3.53 \%$ & $0 \%$ \\
\hline
\end{tabular}

Along with vocabulary obstacles, grammatical structures also bar the students' listening skills. These three statements above represent the results on grammar obstacles and no freshmen picked "strongly disagree". "Agree" was the most frequent choice, whereas that least chosen was "disagree". About $16.47 \%$ of students strongly agreed and $58.82 \%$ agreed that "incorrect grammar is one of the obstacles affecting your listening skill". The remaining ones were $10.59 \%$ who disagreed and $15.52 \%$ who did not know. The next statement had $62.35 \%$ of respondents believing and $8.24 \%$ fully believing that it was hard to identify the main message of the sentence because of not knowing grammar. There was $12.94 \%$ of them who did not believe this and $16.67 \%$ had no idea. Statement 17 "The differences of sentence structures will result in a variety of meanings and implications" received over $83 \%$ of students $(74.12 \%$ selected "agree" and $9.41 \%$ selected "strongly agree"). On the other hand, $3.53 \%$ of students disagreed and $12.94 \%$ selected "no idea". 


\subsection{Pronunciation, intonation, and accent}

Table 5: The students' responses on pronunciation, intonation and accent

\begin{tabular}{|l|c|c|c|c|c|}
\hline Statements & $\begin{array}{c}\text { Strongly } \\
\text { agree }\end{array}$ & Agree & No idea & Disagree & $\begin{array}{c}\text { Strongly } \\
\text { disagree }\end{array}$ \\
\hline $\begin{array}{l}\text { 18. It is hard to identify the main message } \\
\text { of the sentence because of not knowing the } \\
\text { pronunciation. }\end{array}$ & $20.00 \%$ & $56.47 \%$ & $15.29 \%$ & $7.06 \%$ & $1.18 \%$ \\
\hline $\begin{array}{l}\text { 19. You sometimes do not recognize the } \\
\text { sound of native speakers. }\end{array}$ & $24.71 \%$ & $62.35 \%$ & $8.24 \%$ & $4.71 \%$ & $0 \%$ \\
\hline $\begin{array}{l}\text { 20. A given sentence can have different } \\
\text { intonation patterns in different situations. }\end{array}$ & $31.76 \%$ & $61.18 \%$ & $7.06 \%$ & $0 \%$ & $0 \%$ \\
\hline $\begin{array}{l}\text { 21. You find it hard to distinguish which } \\
\text { word is mentioned when hearing a new } \\
\text { accent for the first time. }\end{array}$ & $21.18 \%$ & $56.47 \%$ & $17.65 \%$ & $4.71 \%$ & $0 \%$ \\
\hline
\end{tabular}

Pronunciation, intonation, and accent are extremely important factors affecting students' English listening skills. This part had 4 statements (numbered 18, 19, 20, and 21) and no freshmen picked "strongly disagree", except for the first statement. As can be seen from the above table, it is explicit that more than $70 \%$ of participants had difficulties with them. In statement 18 , about three-fourths $(76.47 \%)$ of respondents concurred that it was hard to identify the main message of the sentence because of not knowing the pronunciation (56.47\% of them agreed and $20 \%$ strongly agreed). Among the others, there were only $1.18 \%$ of them who strongly disagreed, $7.06 \%$ selected "disagree", and $15.29 \%$ did not take any side. The next statement, "you sometimes do not recognize the sound of native speakers" included $24.71 \%$ of them who gave "strongly agree", $62.35 \%$ who gave "agree", $8.24 \%$ had no idea and $4.71 \%$ who chose "disagree". In statement 20 , the students who had no idea followed at $7.06 \%$. Nearly $100 \%$ of them $(31.76 \%$ strongly agreed and $61.18 \%$ agreed) shared that a given sentence could have different intonation patterns in different situations. In the last statement, around $77 \%$ of the respondents $(21.18 \%$ and $56.47 \%)$ found that "it hard to distinguish which word is mentioned when hearing a new accent for the first time". Nevertheless, a few participants (4.71\%) did not think so and $17.65 \%$ did not respond either way.

\subsubsection{Problems from learners}

\section{a. Listening strategy}

This is the next part of the questionnaire, indicating the percentage of the students who had problems with listening strategies. There were three statements, numbered 22, 23, and 24. 
Table 6: Students' problems with listening strategies

\begin{tabular}{|l|c|c|c|c|c|}
\hline Statements & $\begin{array}{c}\text { Strongly } \\
\text { agree }\end{array}$ & Agree & No idea & Disagree & $\begin{array}{c}\text { Strongly } \\
\text { disagree }\end{array}$ \\
\hline $\begin{array}{l}\text { 22. You experience trouble in listening } \\
\text { because you still try to hear word by word } \\
\text { in the text. }\end{array}$ & $15.29 \%$ & $57.65 \%$ & 10.59 & 16.47 & $0 \%$ \\
\hline $\begin{array}{l}\text { 23. It is difficult to keep up with all the } \\
\text { information in the text. }\end{array}$ & $12.94 \%$ & $70.59 \%$ & $9.41 \%$ & $7.06 \%$ & $0 \%$ \\
\hline $\begin{array}{l}\text { 24. You are usually confused when } \\
\text { predicting what speakers are going to say. }\end{array}$ & $11.76 \%$ & $52.94 \%$ & $21.17 \%$ & $14.12 \%$ & $0 \%$ \\
\hline
\end{tabular}

Based on the responses of the students, over $72 \%$ of them $(15.29 \%$ strongly agreed and $57.65 \%$ agreed) reported trouble in listening because they still tried to hear word by word in the text. The rest consisted of $16.47 \%$ of them who gave "disagree" and $10.59 \%$ who had no idea. Additionally, about $83 \%$ of students also realized that it was difficult to keep up with all the information in the text $(12.94 \%$ of them strongly agreed and $70.59 \%$ agreed); however, $7.06 \%$ of them could do that, and $9.41 \%$ of students had no idea. For the last statement, "you are usually confused when predicting what speakers are going to say", $52.94 \%$ of students agreed and $11.76 \%$ of them entirely concurred, while $14.12 \%$ of them gave disagreement and $21.76 \%$ of them gave no comment.

\section{b. Practicing time}

It is really an advantage to spend much more time practicing English listening every day. This topic was also part of the questionnaire. The figure below provides an overview of the participants' practicing time.

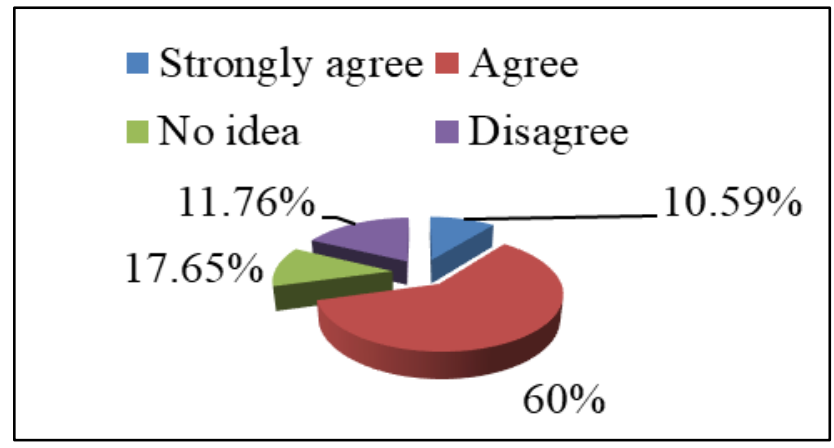

Figure 8: The participants' problems regarding practicing time

From the figures, it was undeniable that approximately $70 \%$ of students $(60 \%$ of them agreed, and $10.59 \%$ strongly agreed) had to face difficulties during the listening process because they only practiced English listening in class. On the contrary, there was only $11.76 \%$ of them having enough time for practicing listening and $17.65 \%$ had no opinion. 


\section{c. Motivation and attitudes}

Motivation and attitudes are key factors helping students succeed in learning English listening because it is a long and difficult process, as shown in the following table:

Table 7: Problems on attitudes and motivation of the respondents

\begin{tabular}{|l|c|c|c|c|c|}
\hline Statements & $\begin{array}{c}\text { Strongly } \\
\text { agree }\end{array}$ & Agree & No idea & Disagree & $\begin{array}{c}\text { Strongly } \\
\text { disagree }\end{array}$ \\
\hline $\begin{array}{l}\text { 26. Psychological obstacles restrict your } \\
\text { ability to receive information. }\end{array}$ & $15.29 \%$ & $54.13 \%$ & $15.29 \%$ & $15.29 \%$ & $0 \%$ \\
\hline $\begin{array}{l}\text { 27. You do not listen well because you do } \\
\text { not have a learning motivation. }\end{array}$ & $7.06 \%$ & $29.41 \%$ & $20.00 \%$ & $38.82 \%$ & $4.70 \%$ \\
\hline $\begin{array}{l}\text { 28. Long listening texts make you stressful } \\
\text { and tired. }\end{array}$ & $15.29 \%$ & $43.53 \%$ & $22.35 \%$ & $18.82 \%$ & $0 \%$ \\
\hline $\begin{array}{l}\text { 29. You are embarrassed and forget } \\
\text { listening strategies for a very long text. }\end{array}$ & $16.47 \%$ & $44.71 \%$ & $21.18 \%$ & $17.65 \%$ & $0 \%$ \\
\hline $\begin{array}{l}\text { 30. You cannot remember all of the } \\
\text { information in the listening text because } \\
\text { the text is so long. }\end{array}$ & $10.59 \%$ & $60.00 \%$ & $14.12 \%$ & $15.29 \%$ & $0 \%$ \\
\hline
\end{tabular}

In statement 26, "psychological obstacles restrict your ability to receive information", there were $54.13 \%$ of participants choosing "agree" and $15.29 \%$ of the total chose "strongly agree". $15.29 \%$ of students gave no comment, as well as "disagree". For statement 27 , the problem was that they did not listen well because they did not have a learning motivation. For this statement, there were $7.06 \%$ of them who strongly agreed, $29.41 \%$ of them who agreed, $38.82 \%$ of the sum who disagreed, $4.70 \%$ who strongly disagreed, and $20 \%$ who said that they did not know. With the next sentence, $43.53 \%$ of respondents believed that they felt stressful and tired when listening to long texts and $15.29 \%$ strongly agreed with this, while the percentage who did not feel this way was $18.82 \%$ and $22.3 \%$ had no idea. The number of students (44.71\% chose "agree" and $16.47 \%$ chose "strongly agree") who were embarrassed and forget listening strategies for a very long text was also higher than the other responses $(17.65 \%$ disagreed and $21.18 \%$ had no idea). Finally, "you cannot remember all of the information in the listening text because the text is so long" had $10.59 \%$ of participants who strongly agreed, $60 \%$ who agreed, $15.29 \%$ who disagreed, $14.12 \%$ who had no comment and no participants strongly disagreed.

\subsubsection{Problems related to background knowledge}

This is the final part of the questionnaire. It shows the effect of background knowledge on learners in the English listening process. Among the 85 students in this research, there were over $70 \%$ of them (22.35\% strongly agreed, and $51.76 \%$ agreed) who stated that background knowledge affects how they make sense of the new information; yet 5.89\% of them selected "disagree", and $20 \%$ had no idea. For the final statement, a majority of students agreed that lack of background knowledge was one of their barriers to listening 
( $13.52 \%$ of them chose "strongly agree" and $63.53 \%$ chose "agree"). Nevertheless, $9.41 \%$ of participants did not respond and $3.53 \%$ of them did not think so, as shown in Table 8 .

Table 8: Students' problems on background knowledge

\begin{tabular}{|l|c|c|c|c|c|}
\hline Statements & $\begin{array}{c}\text { Strongly } \\
\text { agree }\end{array}$ & Agree & No idea & Disagree & $\begin{array}{c}\text { Strongly } \\
\text { disagree }\end{array}$ \\
\hline $\begin{array}{l}\text { 31. Background knowledge affects } \\
\text { how you make sense of the new } \\
\text { information. }\end{array}$ & $22.35 \%$ & $51.76 \%$ & $20.00 \%$ & $5.89 \%$ & $0 \%$ \\
\hline $\begin{array}{l}\text { 32. Lack of background knowledge } \\
\text { is one of your barriers to listening. }\end{array}$ & $23.52 \%$ & $63.53 \%$ & $9.41 \%$ & $3.53 \%$ & $0 \%$ \\
\hline
\end{tabular}

\subsection{Discussion}

The findings of the questionnaire show that though English-majored freshmen at Tay Do University have learned English for a very long time, they are still not good learners. There are many problems that they have to face in the learning process. For instance, coming from urban or rural areas also makes a big difference among learners because students in cities might study with a lot of modern equipment and be taught new, effective methods in high school, whereas the others from the countryside might not. In addition, the number of students who learned all the four skills, namely listening, speaking, reading, and writing, in high school was not equal: in particular, only 37 students $(43.53 \%)$ learned listening. Therefore, this is also another disadvantage for them. For listening, most students found that it was not easy and believed it was very important in learning English as well as in communication. Unfortunately, they did not have a real environment for practicing it regularly, so it is hard for them to master this skill. Furthermore, based on the research results, it is undeniable that to succeed in learning English listening, they have to solve many other problems such as vocabulary, grammar, pronunciation, background knowledge, and other factors.

Firstly, vocabulary was one of the biggest problems of students because without it, they could not listen effectively. While listening, most students felt nervous whenever facing new words and phrases because of lacking vocabulary. When they were unable to understand unfamiliar words, it was difficult to understand the meaning of the text. That made them afraid to listen to new topics at home as well as at school. Another obstacle of students when practicing listening is grammatical structure. A sentence may have various meanings in different situations, so if they do not have enough ability to distinguish these, they will fail. In addition, it is hard for them to understand the exact meaning of a sentence without grammatical structures, especially when listening to a conversation with new grammatical structures. That makes them confused. Pronunciation, intonation, and accent are factors that have a great influence on listening. Most students could not recognize the sounds because sometimes they were pronounced nearly or exactly the same by native speakers. Hence, we cannot deny that it is hard to identify the main message of the sentence. A given sentence can have different intonation in different situations, so it can lead them to make mistakes. Similarly, in a conversation 
with foreigners, when hearing a new accent for the first time, they will find it hard to distinguish which word is mentioned. A suggestion for students is that they should pay more attention to their vocabulary and grammar knowledge as well as their pronunciation, intonation, and accent through applying extensive listening.

Secondly, another notable factor affecting students' listening skills is listening strategies. Trying to hear every word in the English listening text is a big problem for almost all freshmen. They will experience trouble in listening if they still hear word by word in the text. That makes it difficult to keep up with all the information and creates confusion in predicting what speakers are going to say. One more problem belongs to the students' practicing time. Most students stated that they cannot listen well because they only practiced English listening in class. Thus, there is no doubt that they do not have an authentic environment for practicing listening. Moreover, motivation and attitudes toward English listening play very important roles in the learning process. For example, they usually felt stressed and tired when hearing long listening texts. That is the reason why they became embarrassed and forgot listening strategies, and then it was hard for them to remember all of the information in the listening text. This is very clear evidence to prove that psychological obstacles restricted students' ability in receiving information. To overcome these problems, it is recommended that students practice listening regularly in a relaxed and enthusiastic state.

Finally, based on the results of the research, background knowledge was also one of the vital factors affecting students' English listening. In fact, background knowledge affects how students make sense of the new information. However, nearly all of them confirmed that they lack background knowledge. Therefore, whenever listening to strange topics, they might misunderstand or not comprehend it. Accordingly, it is undeniable that lack of background knowledge is one of their barriers in listening. To overcome this difficulty, students should put into practice listening in various ways. They can use some extra materials together with their course books or watch news on the internet to extend their knowledge. Likewise, listening to different topics is a good manner to improve the students' problems.

\section{5: Conclusions, Implications and Recommendations}

\subsection{Conclusions}

English is one of the most popular languages in the world. Through English, it is easier to link countries together, and to make the relationships among them become closer. For that reason, it is very necessary for Vietnamese to know how to learn English in the best way. Similarly, mastering English listening is the first step to acquire it because listening is a prime skill of learners in learning language as well as for communication. For the English-majored freshmen at Tay Do University, they also thought that listening was necessary and helpful. However, during students' English learning process, they had to face many obstacles which mainly affected their English level - especially their listening ability. Thanks to the vital information these students have given, the researcher was able 
to uncover the factors blocking their listening skills. The general problems were linguistic knowledge, (including vocabulary, grammar, pronunciation, intonation, and accent), factors of their own, (including listening strategies, practicing time and environment, motivation, and attitudes), and background knowledge. For instance, being nervous and embarrassed whenever facing new words and phrases in strange listening topics were practical evidence of students' difficulty because of a lack of vocabulary, etc. In fact, when people do something, they should do it with all their heart and their passion, including mastering listening skills. Hence, there is no doubt that they should try their best to overcome their difficulties in learning English listening. They have to spend much more time practicing English listening at home in a diversity of topics to gain knowledge and improve their skills. Further, they can try to communicate with foreigners regularly to get accustomed to real native speakers' voices. As a result, it is hoped that investigating the English-majored freshmen's obstacles in the process of listening will be able to help students to learn listening more effectively.

\subsection{Implications}

Based on the responses of English-majored freshmen at Tay Do University through the questionnaire, it was realized that although they understand completely about the importance of listening in learning English, the students' English listening skills were still not good. It was because they have a lot of obstacles during the listening process. Therefore, the authors of this study hope that these findings can help students recognize their problems more deeply, in order to improve their listening via suitable methods. Furthermore, teachers will realize their students' difficulties regarding linguistics, their own mind, or their background knowledge; and make adjustments for them to study more effectively.

\subsection{Recommendations}

The survey shows that most listeners have lots of problems in English listening, so teachers should find out cautiously their students' obstacles, in order to apply suitable and effective teaching methods for them. This is essential.

This study can be considered as a basis for further research in the future. Thanks to these results, it should now be easier for those who would like to investigate which means may help students to overcome their difficulties in the process of learning English listening.

\section{Conflicts of Interest Statement}

The authors whose names are listed immediately below certify that they have no conflicts of interest, authorship, and disclosures in publication. They confirm that this work is original and has not been published elsewhere, nor is it currently under consideration for publication elsewhere. 


\section{About the authors}

Thi Bao Dung Dang is currently a lecturer at the Faculty of Linguistics and Literature, Tay Do University, Can Tho, Vietnam. She received her MA from Victoria University, Australia. She has just completed her PhD program on comparative linguistics at Viet Nam National University Ho Chi Minh City, University of Social Sciences and Humanities (VNUHCM-USSH). Her research interests include linguistic features of Vietnamese and English political discourse. She has been teaching English for 20 years. She specializes in Cultures of English-speaking countries, English for purposes and language skills.

Van Lanh Le is currently a lecturer at the Faculty of Linguistics and Literature, Tay Do University, Can Tho, Vietnam. He received his MBA from Tay Do University and M.A from Can Tho University. He has been teaching English for 20 years. He specializes in Cultures of English-speaking countries, English for purposes and language skills. At present, he is conducting some research on topics related to test-preparation teaching and collocations.

Van Si Vo is currently the deputy head of the Scientific and International Relations Department of Tay Do University, Can Tho, Vietnam. He is also the co-founder of an English center which mainly delivers courses for children and teenagers. He received his M.A of Principles and Teaching Methodology of English from Can Tho University. He has been teaching English for 19 years. He specializes in English communication and English for purposes. At present, he is interested in and conducting some research on topics related to blended learning (Moodle Platform).

Nhu Ngoc Hua is currently a lecturer at the Faculty of Linguistics and Literature, Tay Do University, Can Tho, Vietnam. She received her MBA from Tay Do University and she is studying a Master's in Linguistics at Hutech. She has been teaching for 10 years. She specializes in English for Business Office, English for Sales and Purchasing. At present, she is conducting research related to using Social Media in language teaching and learning.

My Nguyen has just completed her BA program. Her desire is to become a teacher of English. She is now preparing for her MA program to make her dream come true.

\section{References}

Al-Tamimi \& Shuib (2009). Attitudes and motivation and their impact on the performance of young English as a Foreign Language learners. Joanna Rodiki Petrides Ministry of Education and Culture of Cyprus.

Anderson, A. \& Lynch, T. (2000). Listening. Oxford: Oxford University Press.

Boyle, J. P. (1984). Factors Affecting Listening Comprehension. ELT Journal, 38 (1), 34-38.

Brown, H. (2000). Principles of language learning and teaching. New Jersey: Prentice Hall. Bulletin (1952). The Teaching of Listening. In Arif Saricoban Hacettepe University (Beytepe - Ankara, Turkey) The Internet TEST Journal, Vol. V, No.12. 
Cambell T. (1948). Mindful Learning: 101 Proven Strategies for Student and Teacher Success. Second edition, Corwin Press.

Ellis, R. (1994). The Study of Second Language Acquisition. Oxford: Oxford University Press Feyten, C. M. (1991). The Power of Listening Ability: An Overlooked Dimension in Language Acquisition. The Modern Language Journal 75:173-80.

Gardner, R. C. (2006). Motivation and attitudes in second language learning. London: El Sevior.

Gardner, R. C. \& Lambert, Wallace E. (1972). Attitudes and motivation in second language learning. Rowley: Newbury House Publisher.

A. S. Hasan (2000). Learners' Perceptions of Listening Comprehension Problems: Language, Culture and Curriculum. Language, Culture and Curriculum, Volume 13, $2000 \quad-\quad$ Issue 2, Retrieved from https://www.tandfonline.com/doi/abs/10.1080/07908310008666595

Howatt, A. \& J. Dakin. (1974). Language Laboratory Materials, ed, J. P. B. Allen, S. P. B. Allen, and S. P. Corder.

J. Krishnamurti (1973). The Awaking of Intelligence. Gollancz, Retrieved from https://books.google.ro/books/about/The Awakening of Intelligence.html?id=qI Q8PgAACAAI\&source $=\mathrm{kp}$ book description\&redir $\mathrm{esc}=\mathrm{y}$

Karahan. F. (2007). Language attitudes of Turkish students towards the English language and its use in Turkish context. Retrieved from https://www.researchgate.net/publication/285696531 Language attitudes of Tu rkish students towards the English language and its use in Turkish context

Laufer, B., \& J. H. Hulstijn. (2001). Incidental Vocabulary Acquisition in a Second Language: The Construct of Task-induced Involvement. Retrieved from https://www.researchgate.net/publication/31449377 Incidental vocabulary acqu isition in a second language the construct of Task-Induced Involvement

Livbjerg, I. \& Mees, I. M. (2002). Practical English Phonetics. Denmark: Schonberg.

MacDonough, S. (1983). Psychology in Foreign Language Learning. George, Allen\& Unwin: London.

Nakanishi, T. (2002). Critical Literature Review on Motivation. Journal of Language and Linguistics.

Oxford, R. L. (1993). Research Update on Teaching L2 Listening. System, 21 (2), 205-211.

Purdy M. \& Borisoff D. (1997). Listening in Everyday Life: A Personal and Professional Approach. University Press of America, https://books.google.ro/books/about/Listening in Everyday Life.html?id=xyBiA AAAMAAJ\&source $=\mathrm{kp}$ book description\&redir esc $=\mathrm{y}$

R. Aiken (2002). Attitudes and Related Psychosocial Constructs: Theories, Assessment, and Research. Sage publication.

Richard J. and Gennady W. (2002). Methodology in Language Teaching: An Anthology of Current Practice. Cambridge University Press.

Richards, J. C. (2008). Teaching Listening and Speaking from the theory to the practice. Cambridge University Press. 
Starks, D. and Paltridge B. (1996). A note on using sociolinguistic methods to study non-native attitudes towards English, World Englishes.

Tench P. (1995). The Intonation Systems of English. Bloomsbury.

Thai Pham Anh Duy (2015). Problems Facing English Majored Freshmen at Tay Do University when Learning English Listening Subject. Retrieved from http://115.74.210.103:81/tailieuso/handle/123456789/177

Tseng, S. F. (2012). The Factors Causing Language Anxiety for ESL/EFL Learners in Learning Speaking.

Underwood, M. 1989. Teaching Listening. New York: Longman.

Ur, P. (1984). Teaching of English as a Second or Foreign Language. Cambridge University Press.

Weinstein, C. E. \& R. E. Mayer (1986). The Teaching of Learning Strategies. New York: Macmillan.

Wilhelm, K. (1999). Building an adult ESL knowledge base: An exploratory study using an expert system. Applied Linguistics, Volume 20, Issue 4, December 1999, Pages 425-459, https://doi.org/10.1093/applin/20.4.425

Wilkins, D. (1972). Linguistics in Language Teaching. London: Arnold. 
Thi Bao Dung Dang, Van Lanh Le, My Nguyen, Van Si Vo, Nhu Ngoc Hua

Creative Commons licensing terms

Authors will retain the copyright of their published articles agreeing that a Creative Commons Attribution 4.0 International License (CC BY 4.0 ) terms will be applied to their work. Under the terms of this license, no permission is required from the author(s) or publisher for members of the community to copy, distribute, transmit or adapt the article content, providing a proper, prominent and unambiguous attribution to the authors in a manner that makes clear that the materials are being reused under permission of a Creative Commons License. Views, opinions, and conclusions expressed in this research article are views, opinions and conclusions of the author(s). Open Access Publishing Group and European Journal of English Language Teaching shall not be responsible or answerable for any loss, damage or liability caused in relation to/arising out of conflict of interests, copyright violations and inappropriate or inaccurate use of any kind content related or integrated on the research work. All the published works are meeting the Open Access Publishing requirements and can be freely accessed, shared, modified, distributed and used in educational, commercial and non-commercial purposes under a Creative Commons Attribution 4.0 International License (CC BY 4.0). 